\title{
The chemistry programme
}

\author{
W. P. Cofino ${ }^{1, ~ *, ~ F . ~ S m e d e s ~}{ }^{2}$, S. A. de Jong ${ }^{2}$, A. Abarnou ${ }^{3}$, J. P. Boon ${ }^{4}$, I. Oostingh ${ }^{4}$, \\ I. M. Davies ${ }^{5}$, J. Klungsøyr ${ }^{6}$, S. Wilhelmsen ${ }^{6}$, R. J. Law ${ }^{7}$, J. A. Whinnett ${ }^{7}$, \\ D. Schmidt ${ }^{8}$, S. Wilson ${ }^{9}$ \\ ${ }^{1}$ Ministry of Transport and Public Works, Public Works Department, Tidal Waters Division (TWD), PO Box 20907,2500 EX, \\ The Hague, The Netherlands \\ ${ }^{2}$ Ministry of Transport and Public Works, Public Works Department, Tidal Waters Division (TWD), PO Box 207, \\ 9750 AE Haren, The Netherlands \\ ${ }^{3}$ IFREMER, Centre de Brest, B.P. 70, F-29280 Plouzané, France \\ ${ }^{4}$ Netherlands Institute for Sea Research (NISR), PO Box 59, 1790 AB Den Burg, The Netherlands \\ ${ }^{5}$ The Scottish Office, Agriculture and Fisheries Department, Marine Laboratory, PO Box 101, Victoria Road, \\ Aberdeen AB9 8DB, United Kingdom \\ ${ }^{6}$ Institute of Marine Research (IMRN), PO Box 1870 Nordnes, N-5024 Bergen, Norway \\ ${ }^{7}$ Ministry of Agriculture, Fisheries and Food (MAFF), Fisheries Laboratory, Remembrance Avenue, Burnham on Crouch, \\ Essex CM0 8HA, United Kingdom \\ ${ }^{8}$ Bundesamt für Seeschiffahrt und Hydrographie (BSH), Postfach 3012 20, W-2000 Hamburg 36, Germany \\ ${ }^{9}$ International Council for the Exploration of the Sea (ICES), Palaegade 2-4, DK-1261 Copenhagen K, Denmark
}

\begin{abstract}
The Bremerhaven Workshop required chemical data to help interpret the biological findings. Polychlorobiphenyls, organochlorine pesticides, polycyclic aromatic hydrocarbons, total hydrocarbons and trace metals were determined in sediments, dab liver and benthic invertebrates collected at stations along the German Bight and drilling site transects. In this paper, the chemical data are presented and reviewed.
\end{abstract}

\section{INTRODUCTION}

The Bremerhaven Workshop had the objective of testing and comparing techniques suitable for the monitoring of offshore environmental quality. Two transects were selected for the study: one stretching from the Elbe/Weser Plume to the eastern side of the Dogger Bank and a much more localised transect running $5000 \mathrm{~m}$ down-current of a disused drilling site off the Dutch coast. These transects have been studied quite thoroughly in the past with respect to both hydrography and chemical features (ICES 1989). The information from these studies underpinned the expectation that the biological techniques under investigation would be subject to adequate and realistic test conditions.

To allow interpretation of the biological data, a chemical programme was required to determine the

\footnotetext{
- Present address: Free University, Institute for Environmental Studies, De Boelelaan 1115, 1081 HV Amsterdam, The Netherlands
}

degree of contamination along the transects. It was intended that this programme would study the same samples as were investigated by the biological effect techniques, or at least samples taken from the same populations. The ICES Marine Chemistry Working Group was requested to provide assistance. Six laboratories agreed to collaborate and to undertake chemical analyses of biological tissues and sediments. The German BSH agreed to provide data on trace metals in seawater along the German Bight transect obtained in about the same period in the context of its routine monitoring programme. In this paper, the design of the chemistry programme is discussed and an overview of the results is given. The chemical data is tabulated in full in Appendix 1 of this Special Volume.

\section{DESIGN OF THE CHEMISTRY PROGRAMME}

The objectives of the chemistry programme were to assess the level of contamination and the spatial distribution of chemicals along the transects. This infor- 
mation was necessary to interpret the results of the biological techniques deployed. The contaminants to be studied were the trace metals $\mathrm{As}, \mathrm{Cd}, \mathrm{Cu}, \mathrm{Pb}, \mathrm{Zn}$ and $\mathrm{Hg}$, polycyclic aromatic hydrocarbons (PAHs), total hydrocarbons (THCs), polychlorinated biphenyls (PCBs) and organochlorine pesticides (OCs). A compromise had to be found between the requested and offered chemical support within constraints imposed by logistics. In a meeting of the coordinators it was decided to focus the programme on sediment, dab Limanda limanda, and the benthic invertebrates Pagurus bernhardus, Ophiura texturata, Nephthys hombergii, Aphrodite aculeata and Nucula nitidosa. The guidelines adopted by the Joint Monitoring Group and the North Sea Task Force were to be applied where appropriate. Contaminants in sediments were to be measured in both the total, unfractionated material and in the fraction $<63 \mu \mathrm{m}$. Dab livers were to be dissected from fish with a length between 19 and $24 \mathrm{~cm}$. The North Sea Task Force (NSTF) and Joint Monitoring Group (JMG) guidelines require that As and $\mathrm{Hg}$ are measured in fish muscle instead of fish liver. For practical reasons, however, As and $\mathrm{Hg}$ were determined in dab liver. No guidelines are available for the benthic species.

All samples were to be taken in replicate in order to obtain a dataset which would permit justifiable inferences. The number of replicates $N$ was estimated on the basis of the formula

$$
N \geq 2\left(t_{\alpha|v|}+t_{2(1-P)|v|}\right)^{2}(\sigma / \Delta)^{2} \approx 16(\sigma / \Delta)^{2}
$$

where $\alpha$ = significance level $v$ = degrees of freedom of sample standard deviation; $t_{\alpha|v|}=$ value from a 2 -tailed $t$-table with $v$ degrees of freedom and corresponding to a probability $\alpha ; P$ is the desired probability that a difference will be found to be significant; $\sigma$ is the (true) standard deviation; and $\Delta$ represents the smallest true difference that is to be detected (Hendrix 1979, Sokal \& Rohlf 1981)

As only crude estimates were available for standard deviations, it was considered most appropriate to take 6 samples at each station for each compartment. The samples of dab liver and the benthic organisms were to be composed by homogenization of pooled livers from 15 individual organisms. This strategy was chosen in order to minimize variance in the data for a station, and in order to obtain sufficient material for the preparation and distribution of subsamples. The available laboratory support did not allow complete analysis of 6 unfractionated and fractionated sediment samples at each station. As a compromise, 3 samples were taken at the German Bight Stns 4 to 9 and at the drilling site Stns A \& R, and 2 samples at the German Bight Stns 1 to 3 and the drilling site Stns B to G (see Stebbing
\& Dethlefsen 1992 for lists of station positions and nomenclature). The latter was considered sufficient because the stations concerned are very close to each other.

Staff from the laboratories participating in the chemical programme were not present at the workshop and sampling had to be done by workshop participants. It was decided to minimize sample handling on board the ships in order to reduce problems with contamination. The dabs were to be stored at $-20^{\circ} \mathrm{C}$ as soon as possible after collection. This approach is acceptable, provided that the rate of freezing is sufficient. The benthic organisms were to be washed with seawater, wrapped in polyethylene bags and stored at $-20^{\circ} \mathrm{C}$ as fast as possible. Sediments were transferred in polyethylene bags and kept frozen.

The analytical work was allocated in such a manner that all analyses of a particular contaminant/matrix combination (e.g. PCBs in dab liver) were performed by one laboratory. With this approach, the dataset is not complicated by interlaboratory differences. The contributions of the participating laboratories are as follows: MAFF, Burnham on Crouch, UK: PAHs and THCs in sediment; NISR, Texel, Netherlands: PCBs in unfractionated sediment; IFREMER, Brest, France: PCBs in the sediment fraction $<63 \mu \mathrm{m}$; Institute of Marine Research, Bergen, Norway: PCBs and OCs in dab liver; SOAFD Marine Laboratory, Aberdeen, UK: sediment characteristics, trace metals in sediments and dab liver; Tidal Waters Division (TWD), Haren, Netherlands: sample preparation, PCBs, PAHs and trace metals in benthic species

BSH, Hamburg, Germany, provided data on trace metals in filtered and unfiltered sea water. These samples were obtained from March 5 to 12, 1990 during one of the cruises of the OPTINOM/TUVAS project. Some of these stations located along the German Bight gradient were selected to coincide with those used by the workshop

\section{MATERIALS AND METHODS}

Dissection and pooling of the livers of female dab was carried out in Bremerhaven by technicians of Tidal Waters Division. All samples were transported to the laboratory of Tidal Waters Division in Haren, The Netherlands. Here, homogenization of the samples, preparation of subsamples and distribution to all participating laboratories took place.

Sediments were thawed and passed through a $2 \mathrm{~mm}$ sieve to remove coarse particles. The fraction $<63 \mu \mathrm{m}$ was obtained with a home-made device (Klamer et al. 1990). Subsamples were taken for analysis of PCBs, trace metals and PAHs. The pooled dab livers were ho- 
mogenised in Haren using an Ultra Turrax with a titanium blender. Subsamples were taken for the analyses on PCBs and trace metals. The samples of Pagurus bernhardus were washed with deionized water. The abdomen was removed with a titanium knife. Pooled abdomens were homogenized using an Ultra Turrax with titanium blender. The samples of Aphrodite aculeata were washed with deionised water. The soft tissues were fractionated after immersing the organisms in liquid nitrogen. Homogenization was achieved as for the samples of $P$. bernhardus.

The main features of the analytical procedures are summarized below. More information on the methods and the quality assurance procedures can be obtained from the respective laboratories.

Trace metals. Sediments (SOAFD): $\mathrm{Cd}, \mathrm{Cu}, \mathrm{Pb}$ and $\mathrm{Zn}$ concentrations were determined by digestion of 3 to $4 \mathrm{~g}$ of dry material in boiling concentrated nitric acid and hydrogen peroxide. The resulting mixture was diluted with distilled water, centrifuged, the solid residue washed again and the combined supernatant liquids made up to $25 \mathrm{ml}$ volume. Concentrations were determined by flame atomic absorption spectrometry. As concentrations were determined on the same digest by reduction of a small aliquot using borohydride solution. The arsine generated was detected by AAS using a heated quartz tube. $\mathrm{Hg}$ in the digest was determined by cold vapour AAS.

Dab liver (SOAFD): $\mathrm{Cd}, \mathrm{Cu}, \mathrm{Pb}$ and $\mathrm{Zn}$ concentrations were determined by digestion in boiling concentrated nitric acid and estimation by flame AAS. As was determined by digestion of aliquots of tissue in a mixture of nitric acid, sulphuric acid and vanadium pentoxide. Reduction of arsenic to arsine was accomplished with borohydride solution; the arsine generated was detected by AAS as above. Hg concentrations were determined by combustion of tissue in a quartz tube furnace in a stream of oxygen. The liberated mercury was trapped in a sulphuric acid/potassium permanganate solution and determined by cold vapour AAS.

Benthic invertebrates (TWD): Tissues of Pagurus bernhardus and Aphrodite aculeata were digested with concentrated nitric acid following the Dutch standard NEN 6439. Cd, $\mathrm{Cu}$ and $\mathrm{Pb}$ were measured with graphite furnace atomic absorption spectrometry employing the L'vov platform, Zn was measured with flame atomic absorption spectrometry and $\mathrm{Hg}$ with cold vapor atomic absorption spectrometry.

Seawater (BSH): Water samples were acquired with the 'Mercos' sampling system (Freimann et al. 1983). Unfiltered samples were acidified either in situ or on board. Filtered samples were obtained with $0.4 \mu \mathrm{m}$ 'Nuclepore' membrane filters. All sample manipulations on board the ship took place on clean benches.
Samples for mercury were stored at ambient temperatures; samples for the other metals were stored deep frozen. The metals $\mathrm{Mn}, \mathrm{Fe}, \mathrm{Co}, \mathrm{Ni}, \mathrm{Cu}, \mathrm{Zn}, \mathrm{Pb}$ and $\mathrm{U}$ were determined by total reflection $X$-ray fluorescence analysis (Freimann \& Schmidt 1989). Mercury was determined by cold vapour AAS after enrichment on finely dispersed gold (Schmidt \& Wendlandt 1987). Cadmium was measured by graphite furnace AAS (Schmidt et al. 1986).

PCBs and OCs. Sediment - unfractionated (NISR): PCBs in unfractionated sediments were wet-extracted with acetone in an Erlenmeyer flask. For each $10 \mathrm{~g}$ of sediment, $15 \mathrm{ml}$ of acetone were used. Samples were shaken overnight. After most of the sediment had been allowed to settle, the overlying fluid was filtered over a glass-fibre filter (Whatman GF-C, $15 \mathrm{~cm}$ diameter), then this filter was also put into the Erlenmeyer flask containing the settled sediment. The acetone phase was stored for later treatment. Subsequently, approximately one sediment volume of hexane/acetone 70:30 was added, the flasks were shaken for $1.5 \mathrm{~h}$, and the sediment was allowed to settle. The overlying layer was poured off into a separation funnel and combined with the acetone extract. For each $10 \mathrm{~g}$ of original sediment, $10 \mathrm{ml}$ of water was added and thoroughly mixed. After phase separation, the water layer was discarded, while the organic phase was put into a Kuderna Danish evaporation unit and concentrated to approximately $1 \mathrm{ml}$. Elemental sulfur was removed with a tetra-butyl ammonium sulfite reagent (( $\mathrm{TBA})_{2} \mathrm{SO}_{3}$ ) according to Jensen et al. (1977).

Clean-up with basic alumina (ICN alumina B Super I, Lamers \& Pleuger) and silica (Merck cat. no. 7754) fractionation have been described in Duinker \& Hillebrand (1978) and Boon et al. (1985). Quantification was done on a HP 5880 gas chromatograph equipped with a $50 \mathrm{~m} \times 0.25 \mathrm{~mm} \mathrm{SE}-54$ capillary column (Chrompack, Middelburg, The Netherlands). The carrier gas was helium. Further details are given in Boon et al. (1985).

Sieved sediments (IFREMER): About 10 to $20 \mathrm{~g}$ of dried material was Soxhlet-extracted with a mixture of 80:20 hexane:acetone. The extract was concentrated to about $1 \mathrm{ml}$, and cleaned by Florisil column chromatography. Sulphur removal was accomplished with mercury. The hexane was removed by evaporation employing a stream of nitrogen gas, then $0.5 \mathrm{ml}$ iso-octane was added. For the separation of the compounds, 2 columns were employed: an HP5 $50 \mathrm{~m} \times$ $0.31 \mathrm{~mm}$ ID, filmlayer $0.17 \mu \mathrm{m}$, and a CPSil9 $50 \mathrm{~m} \times$ $0.23 \mathrm{~mm}, 0.2 \mu \mathrm{m}$ filmlayer.

Dab liver (IMRN): $4 \mathrm{~g}$ of liver were transferred into a centrifugal tube together with CB-53 as internal standard and $50 \mathrm{ml}$ redistilled acetone. The sample was homogenized in an Ultra turrax and centrifuged for 
5 min at $3000 \mathrm{rpm}$. The acetone extract was decanted into a separating funnel containing $60 \mathrm{ml} 0.2 \mathrm{M} \mathrm{NaCl}$ in $10 \mathrm{mM}$ phosphoric acid. The liver was extracted twice, first with $50 \mathrm{ml}$ hexane:acetone $(75: 25)$, then with $10 \mathrm{ml}$ hexane: diethylether $(9: 1)$. The combined extract was shaken with the $\mathrm{NaCl} / \mathrm{H}_{3} \mathrm{PO}_{4}$ solution in the separating funnel and, after removal of the aqueous solution, with $20 \mathrm{ml}$ water. The sample extracts were divided into 2 equal parts. In the first, fat was removed with concentrated sulphuric acid for the determination of PCBs, HCHs, HCB, aldrin, DDT and derivatives thereof. The second part of the extract was used for the determination of dieldrin and endrin, fat being removed with saponification using methanolic $\mathrm{KOH}$. Sample clean-up was achieved using Florisil column chromatography. Final analysis was carried out on a Hewlett Packard 5880A GC (ECD) equipped with a SE-54 CB $50 \mathrm{~m} \times 0.20 \mathrm{~mm}$ ID fused silica capillary column, filmlayer 0.1 í $\mu \mathrm{m}$. Hydrogen was used ds carrier gas.

Benthic invertebrates (TWD): Samples of Aphrodite aculeata and Pagurus bernhardus were spiked with an internal standard and Soxhlet-extracted with a mixture of hexane:acetone $(75: 25)$ for $4 \mathrm{~h}$. Clean-up was accomplished using Florisil column chromatography, elution with hexane, a concentration step, $\mathrm{SiO}_{2}$ column chromatography and elution with hexane. The extract was concentrated and a second internal standard was added. Separation was achieved with a SE $54,50 \mathrm{~m} \times$ $0.15 \mathrm{~mm}, 0.2 \mu \mathrm{m}$ column and a CP Sil 19CB, $50 \mathrm{~m} x$ $0.15 \mathrm{~mm}, 0.2 \mu \mathrm{m}$ column. Hydrogen was used as carrier gas

PAHs and hydrocarbons. Sediments (MAFF): Sediment samples were analysed for total hydrocarbons and specific PAH as described previously (Law et al. 1988). Briefly, alkaline digestion of the sediments was followed by pentane extraction and analysis by fluorescence spectrometry. Following clean-up on alumina, the extracts were analysed for total hydrocarbons by gas chromatography and for specific PAHs by GC-MS.

Benthic invertebrates (TWD): The determinations of PAHs in Aphrodite aculeata and Pagurus bernhardus employed the same preparatory procedure as for the PCBs described above, up to and including the cleanup on the $\mathrm{SiO}_{2}$ column. After concentration, the extract was put on top of an $\mathrm{Al}_{2} \mathrm{O}_{3}$ column. This column was dried gently with nitrogen and eluted with methanol. A second internal standard was added at this point. Separation and analysis of PAHs is achieved with a methanol-water gradient on a Vydac $201 \mathrm{TPB}-525 \mathrm{~cm}$ $\times 4.6 \mathrm{~mm}$ reversed phase column. The PAHs are measured with a Hewlett Packard 1090 HPLC equipped with 2 programmable fluorescence detectors (Hewlett Packard HP 1046A and Perkin Elmer LS40).

\section{RESULTS AND DISCUSSION}

All data are given in Appendix 1 at the end of this volume.

\section{Sampling}

Sampling for the chemistry programme was fraught with problems. The sampling scheme and protocols were not adhered to and the administration of the samples in the field was not wholly effective. This can in part be attributed to a lack of personnel on the vessels whose main responsibility was the samples for chemical analysis.

Sediments were collected at all stations either with a Van Veen grab or a boxcorer. Dab liver samples were collected at German Bight Stns 3 to 9 and at drilling site Stns A \& R. It appeared, however, that in some cases the freezing rate had been less than appropriate and that deterioration of livers had occurred. The most affected livers were discarded, and pooled samples of acceptable quality were formed.

Of the benthic invertebrates only Pagurus bernhardus was collected at all stations. The number of organisms, however, was rather small, and permitted pooling to only a limited extent. No other benthic organisms apart from Aphrodite aculeata were obtained in sufficient quantities for analysis. Thus data could be generated for both epifaunal and infaunal benthic species.

\section{General characteristics of compartments studied}

The sediments collected along the German Bight transect become progressively more coarse from Stn 1 towards $\operatorname{Stn} 9$. The characteristics of the sediments collected at the drilling site stations are comparable to those of the German Bight Stns 4 to 7 . The sediment characteristics, viz. the percentage $<63 \mu \mathrm{m}$, inorganic carbon, organic carbon, and water content, appear to be highly correlated, the correlation coefficient ranging between 0.85 and 0.97 .

The composition of the sediment fraction $<63 \mu \mathrm{m}$ appears to be rather consistent for all stations as assessed by inspection of the data on organic carbon, inorganic carbon and total nitrogen. On the German Bight transect, organic carbon appears to be about $2.5 \%$, apart from Stn 9 at which high values are encountered (about $5 \%$ ). Inorganic carbon exhibits a tendency to decrease over the transect, with a small increase at Stn 9 . Total nitrogen is quite constant at about $0.3 \%$, increasing to $0.6 \%$ at Stn 9 . The organic carbon and total nitrogen contents in the fraction $<63 \mu \mathrm{m}$ of sedi- 
ments collected at Stn 9 are significantly higher than those in the sediments of Stns $6,7 \& 8$ ( $p=0.024$ and $<0.001$, respectively). This may reflect the higher biological productivity, which is associated with the presence of frontal systems around the Dogger Bank area (ISEPNS 1988).

It is noted that 2 strong gales in January and February 1990 deposited large quantities of sediments in the area of the drilling site transect. This is demonstrated by the REMOTS pictures which show fresh deposition of several centimetres of sandy sediment on top of the old, probably contaminated sediment (Rumohr \& Schomann 1992). Only the top 5 to $6 \mathrm{~cm}$ of sediments were sampled at the drilling site transect. It is therefore likely that the sediment data do not correspond with the layer which had been contaminated during the exploration drilling activities conducted in 1987.

The percentage lipids in the dab livers collected at German Bight Stn 3 were higher than those of other stations. This percentage tended to decrease from Stns 3 to 6 , followed by an increase to Stn 9 . The lipid content in dab livers at $\operatorname{Stn} 9$ was significantly higher than the lipid content found at Stns 6, $7 \& 8(p=0.008)$. The percentage lipid in samples obtained at the 2 drilling site stations was quite similar to those found at German Bight Stns 6, 7 \& 8

The lipid content of the abdomens of Pagurus bernhardus ranged from about 150 to $260 \mathrm{mg} \mathrm{g}^{-1}$ dry weight. The lipid content of $P$. bernhardus abdomens collected at Stn 9 was significantly lower than the contents encountered at Stns 3 to $8(p=0.001)$. The lipid contents in Aphrodite aculeata ranged from about 28 to $55 \mathrm{mg} \mathrm{g}^{-1}$ dry weight.

\section{Trace metals}

Unfractionated sediments. The concentrations of all trace metals in unfractionated sediments, viz. As, Cd, $\mathrm{Cu}, \mathrm{Hg}, \mathrm{Pb}$ and $\mathrm{Zn}$, decrease monotonously along the German Bight transect, in accordance with the increase in grain size of the sediments. The metal concentrations in the drilling site sediments resemble those found for the offshore German Bight stations (5 to 9). No attempt has been made to correct for the grain size effects.

Sieved sediments. Normalization of concentrations of contaminants may be achieved by determining the constituents in the sediment fraction obtained by sieving over $63 \mu \mathrm{m}$. Concentrations of As generally varied between 8 and $20 \mathrm{mg} \mathrm{kg}^{-1}$ dry weight, apart from one sample from each of Stns $8 \& 9$, which were 35 and 30 mg $\mathrm{kg}^{-1}$ dry weight. Cd exhibited a gradual decrease between Stns $1 \& 6$. The $\mathrm{Cd}$ concentrations at Stn 9 were significantly higher than at Stns $6,7 \& 8(\mathrm{p}=$ 0.024). The drilling site stations had $\mathrm{Cd}$ concentrations very similar to those encountered at German Bight Stns $6,7 \& 8$ (Fig. 1). The findings for $\mathrm{Hg}$ resembled those of Cd to some extent. A decrease from Stns 1 to 8

Deb liver (mg/kg dry weight)

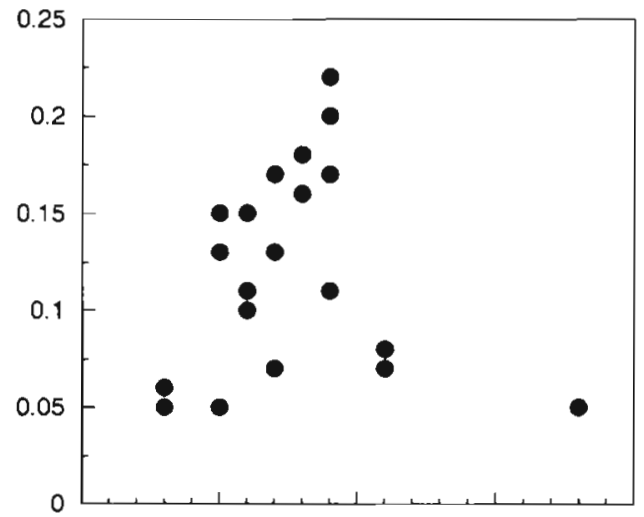

Pagurus bernhardus (mg/kg dry weight)

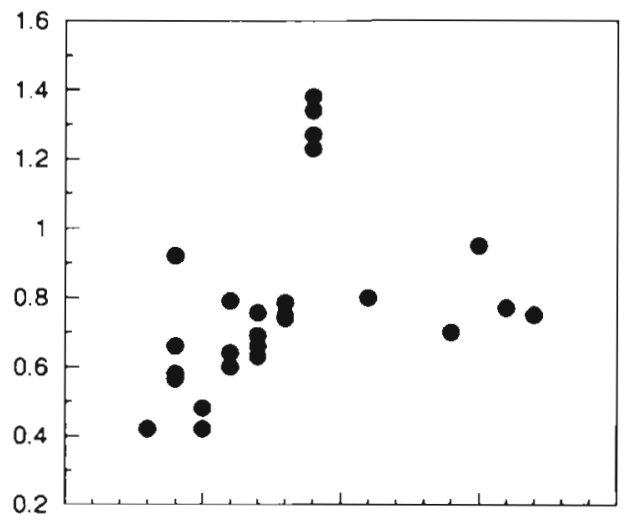

Sieved sediment (mg/kg dry weight)

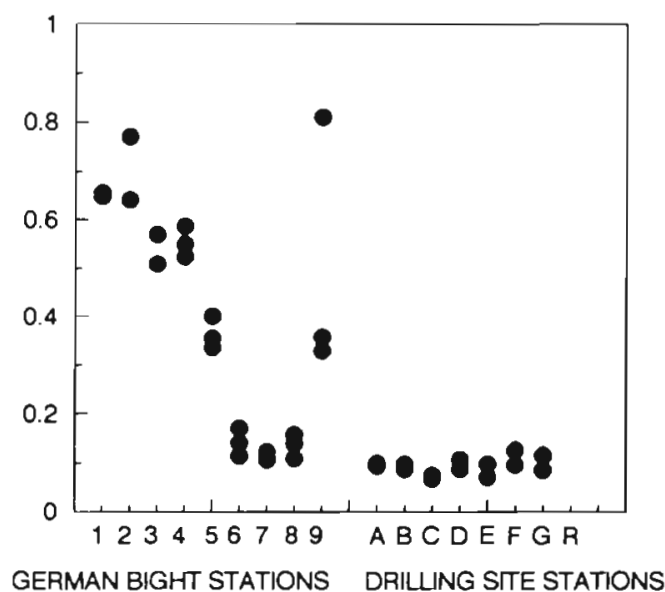

Fig. 1. Spatial distribution of Cd along the German Bight and Drilling Site transects as reflected in dab liver, Pagurus bernhardus, and sieved sediments 
was observed, followed by an increase at Stn 9 . The sieved sediment concentrations of $\mathrm{Hg}$ at the drilling site stations were quite homogeneous, and ranged between 0.1 and $0.24 \mathrm{mg} \mathrm{kg}^{-1} \mathrm{dry}$ weight. The concentrations of $\mathrm{Cu}$ were in a fairly small range (16 to $26 \mathrm{mg}$ $\mathrm{kg}^{-1}$ dry weight), except for an outlier at Stn 8 at 40.7 $\mathrm{mg} \mathrm{kg} \mathrm{kg}^{-1}$ dry weight. The concentration of $\mathrm{Pb}$ appeared to be more dispersed than those observed for the other metals and ranged between 33 and $102 \mathrm{mg} \mathrm{kg}^{-1}$ dry weight, with the exception of Stn 9, where it was significantly higher than the concentrations encountered at Stns $6,7 \& 8(p=0.047)$. Zn, finally, showed a clear decrease along the German Bight transect. German Bight Stns 6 to 9 and all the drilling site stations exhibited quite similar concentrations for $\mathrm{Zn}$. It is noted that the enhanced levels of $\mathrm{Cd}, \mathrm{Hg}$ and $\mathrm{Pb}$ in sieved sediments obtained at Stn 9 may be related to the high organic carbon content of the material.

Dab liver. Trace metai concentrations in dab liver obtained along the German Bight transect did not clearly reflect the pattern of metal concentrations in the sieved sediments. The concentration of As increased from Stn 3 to 8 , but decreased towards Stn 9 . The concentrations of As at the 2 drilling site stations appeared to be in the same range as the German Bight Stns 7 \& 8. Zn concentrations in dab liver appeared to be quite similar for all samples analysed and are in the range 16 to $29 \mathrm{mg} \mathrm{kg}^{-1}$ dry weight. Cu concentrations in dab liver are quite similar at all stations except German Bight Stn 9, where relatively low concentrations are observed. $\mathrm{Cd}$ in dab liver exhibited a clear increase along the German Bight transect going from Stn 3 to 9 . Cd in livers of dab acquired at the drilling site transect were comparable to the $C d$ concentrations observed in dab liver at German Bight Stn 3 (Fig. 1). The $\mathrm{Hg}$ concentrations were quite similar for all dab liver samples, and ranged between 0.05 and $0.13 \mathrm{mg} \mathrm{kg}^{-1}$ dry weight. Pb in dab livers was lower than the limit of detection $\left(0.5 \mathrm{mg} \mathrm{kg}^{-1}\right)$ in all samples.

Benthic invertebrates. Cd concentrations in Pagurus bernhardus exhibited a slight increase going from German Bight Stn 3 to Stn 8. Cd concentrations in $P$. bernhardus sampled at Stn 9 were significantly higher than those observed at Stns $6,7 \& 8$ ( $p<0.001)$. Few $P$. bernhardus samples were available for the drilling site transect. These concentrations were between 0.75 and $0.95 \mathrm{mg} \mathrm{kg}^{-1}$ dry weight, approximately comparable to the German Bight Stns 6, 7 \& 8 (Fig. 1). Cd in Aphrodite aculeata exhibited a somewhat different profile, the highest concentration being observed at Stn 6 . The $\mathrm{Cd}$ concentrations in $\mathrm{A}$. aculeata collected along the drilling site transect were distinctly higher than those found in German Bight samples. The profiles of $\mathrm{Cu}$ in $P$. bernhardus and $A$. aculeata along the German Bight transect showed no spatial trend. The concentrations of Cu in $P$. bernhardus and $A$. aculeata ranged for all stations from 140 to 210 and from 12 to $24 \mathrm{mg} \mathrm{kg}^{-1}$ dry weight respectively. $\mathrm{Hg}$ concentrations in $P$. bernhardus showed a decrease along the German Bight transect, and ranged between 0.17 and $0.43 \mathrm{mg} \mathrm{kg}^{-1}$ dry weight. Hg concentrations in the $A$. aculeata samples were between 0.17 and $0.28 \mathrm{mg} \mathrm{kg}^{-1}$ dry weight. $\mathrm{Pb}$ exhibited an irregular pattern in $P$. bermhardus and $A$ aculeata. Stn 6 revealed the highest concentrations of $\mathrm{Pb}$ in $P$. bernhardus (an average of $5 \mathrm{mg} \mathrm{kg}^{-1}$ dry weight); Stn 7 was distinctly lower $\left(0.8 \mathrm{mg} \mathrm{kg}^{-1}\right.$ dry weight). The other stations along the German Bight and drilling site transects had $\mathrm{Pb}$ average concentrations in $P$. bernhardus of about $2 \mathrm{mg} \mathrm{kg}^{-1}$. For the $A$. aculeata samples, $\mathrm{Pb}$ ranged between 10 and $33 \mathrm{mg}$ $\mathrm{kg}^{-1}$ dry weight at the German Bight stations. The $\mathrm{Pb}$ concentrations in $A$. aculeata samples collected at the drilling site stations exhibited less scatter, and fell within the range found for the German Bight transect. The concentrations of $\mathrm{Zn}$ in $P$. bernhardus were comparable at all stations, and varied between 110 and $140 \mathrm{mg} \mathrm{kg}^{-1}$ dry weight. A. aculeata exhibited similar patterns and concentrations. At Stns 4, 5 \& 6, the metals $\mathrm{Cd}, \mathrm{Cu}, \mathrm{Hg}, \mathrm{Pb}$ and $\mathrm{Zn}$ were also determined in eggs of $P$. bernhardus. The concentrations of $\mathrm{Cd}, \mathrm{Cu}$ and $\mathrm{Hg}$ in $P$. bernhardus eggs were lower than in abdomens; the concentrations of $\mathrm{Pb}$ and $\mathrm{Zn}$ in these $2 \mathrm{com}$ partments were comparable.

Seawater. For metals the concentrations are given in Table 1. For most metals, possible trends are masked by the variability in the data.

\section{Chlorobiphenyls and other organochlorines}

Unfractionated sediments and other organochlorines. Concentrations of chlorobiphenyls decrease steadily along the German Bight transect (e.g. Fig. 2). To a large degree this was due to the decrease in organic carbon content in the sediments. When the concentrations were normalised to organic carbon, a decrease was still observed except for Stn 9 where a slight increase could be seen.

Table 1. Concentrations of metals in seawater

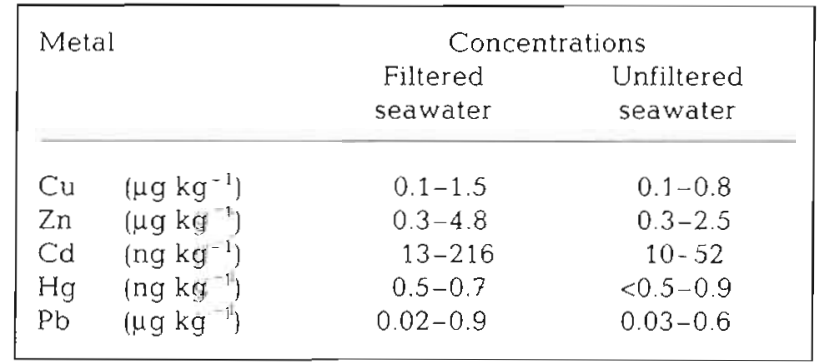


Sieved sediments. The concentrations of all chlorobiphenyls determined decreased along the German Bight transect from Stns 1 to 8, and tended to increase at Stn 9. The enhanced organic carbon content in the Stn 9 sieved sediments may have caused this trend. When the PCB concentrations were normalized with respect to organic carbon, the increase at Station 9 was no longer apparent.

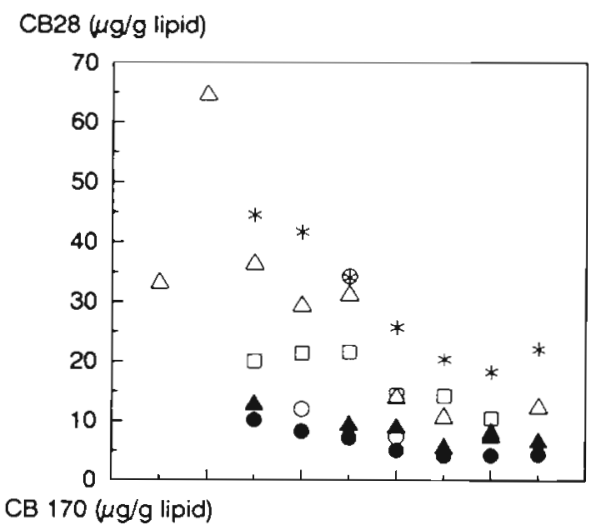

CB $170(\mu \mathrm{g} / \mathrm{g}$ lipid)
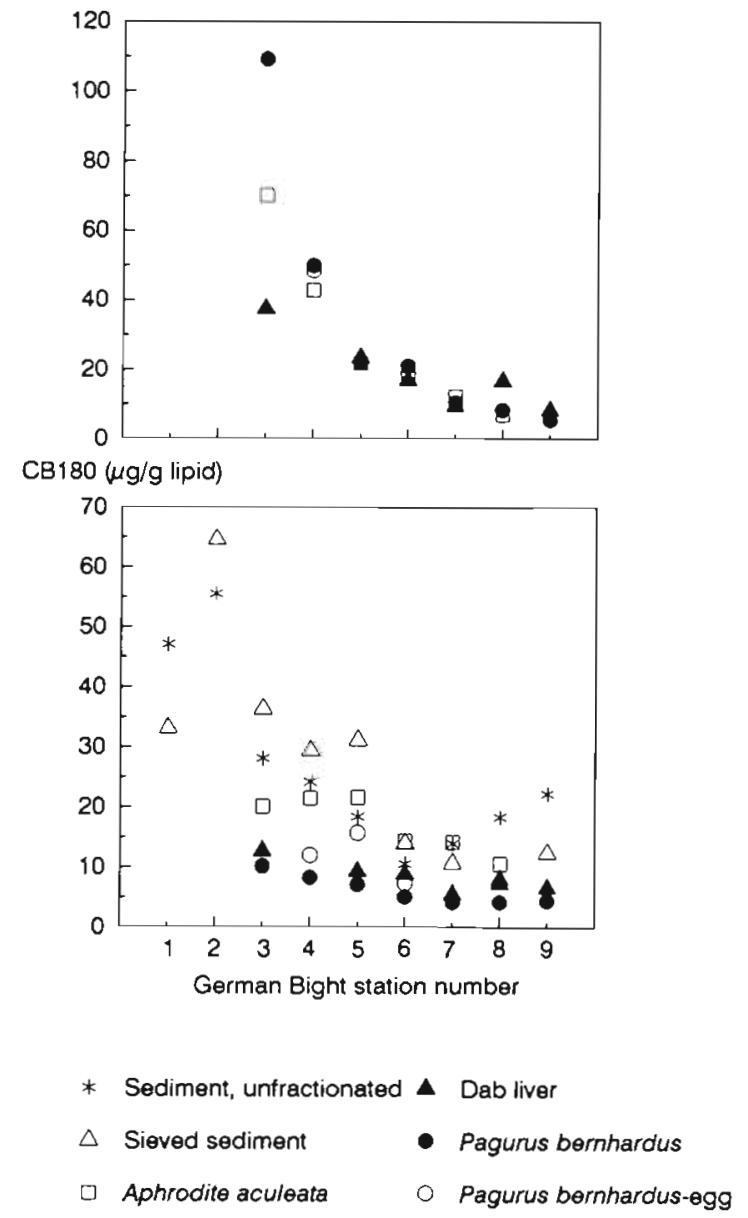

Fig. 2. Lipid normalized concentrations of CB-28, CB-170 and CB-180 in dab liver, benthic invertebrates and unfractionated and sieved sediments. For the latter 2 compartments, normalization is effectuated using organic carbon
Dab liver. The concentrations of chlorobiphenyls decreased steadily from Stns 3 to 9 (Fig. 2). Dab livers from 2 drilling site stations were also analysed for PCBs. The PCB concentrations in these samples resembled quite closely the levels observed at the German Bight Stns 7, 8 \& 9. Several organochlorine pesticides were determined in dab liver (see Appendix 1). The concentrations of most compounds (e.g. aldrin, HCB, DDT) were comparable at all stations investigated. Lindane $(\gamma-\mathrm{HCH})$ decreased clearly along the German Bight transect, and had a distinctly lower concentration at Stn 9.

Benthic invertebrates. The concentrations of chlorobiphenyls in Pagurus bernhardus and Aphrodite aculeata decreased along the German Bight transect, as found for the other compartments. It appears that the lipid-normalized concentrations of PCBs are quite similar for the different species studied. This is illustrated in Fig. 2, in which the lipid-normalized concentrations of CB-28, CB-170 and CB-180 are given for biota and sediments. At Stns 3,4\& 5 the lipid-normalized concentrations of CB-28 in $A$. aculeata were significantly higher than those in $P$. bernhardus. The concentrations in $P$. bernhardus eggs, $P$. bernhardus abdomen and dab liver were quite similar. An inspection of the data reveals that the lipid-normalized concentrations of the lower chlorinated congeners were all higher in $A$. aculeata, and that the difference decreased with increasing lipophilicity of the higher chlorinated CB congeners. The relationship of PCB concentrations in $P$. bernhardus and $P$. bernhardus eggs has been studied by Knickmeyer \& Steinhart (1988). These authors observed that the eggs have higher concentrations of lower chlorinated PCB congeners in the summer, but that the abdomen and egg concentrations are similar in the winter, as found in this study.

It was observed that the lipid-normalized CB-180 concentrations for Pagurus bernhardus, $P$. bernhardus eggs and Aphrodite aculeata were practically identical for the German Bight Stns 4 and onwards. A relatively large difference was observed for Stn 3. The lipidnormalized CB-180 concentrations in dab liver were slightly higher. The concentrations of CB-28 and CB180 , normalized to organic carbon, in sieved and unfractionated sediments reveal levels and trends which are quite similar to those found in biota.

It should be noted that the determinations of lipid and PCBs in the unfractionated and sieved sediments, the dab liver and the benthic species were performed by 4 different laboratories. In this context, the correspondence is considered quite good. The findings support the conclusion that partitioning plays an important role in the (bio)accumulation of PCBs (Boon \& Duinker 1985, Boon et al. 1985, Delbeke \& Joiris 1988). 
The ratios of CB-18, CB-28 and CB-31 to CB-180 increased from Stn 3 to Stn 9 for the benthic invertebrates. The ratio $\mathrm{CB}-28 / \mathrm{CB}-180$ in dab liver was approximately constant along the German Bight transect. The trend of $\mathrm{CB}-28 / \mathrm{CB}-180$ in the sieved sediments is not clear owing to a large spread in the data, but a trend to an increase seems to be present. In unfractionated sediments, the ratio CB-28/CB-180 exhibited a maximum at Stn 6, due to relatively low CB-180 concentrations (Fig. 3). On the basis of the persistence of CB-28 and CB-180, it may be expected that the ratio CB-28/CB-180 would decrease along the transect if riverine input were the major source for the entire area. Since this is not found, the observations may point to an increasing importance of atmospheric inputs for the more offshore area of the transect, where the lowest absolute concentrations occur. Water flows around the Dogger Bank in a roughly circular manner. This implies that the age of the water will become higher towards the Dogger Bank (van Pagee 1988). The effects of atmospheric deposition increase with the age of the water. CB-28 has a relatively high volatility, implying that atmospheric deposition will be more important for this compound than for CB-180. A similar phenomenon was reported by Boon et al. (1985).

\section{Total hydrocarbons by UVF and GC}

THC-UV concentrations in total sediments declined from ca 75 to ca $1 \mu \mathrm{g} \mathrm{g}^{-1}$ dry weight Ekofisk crude oil
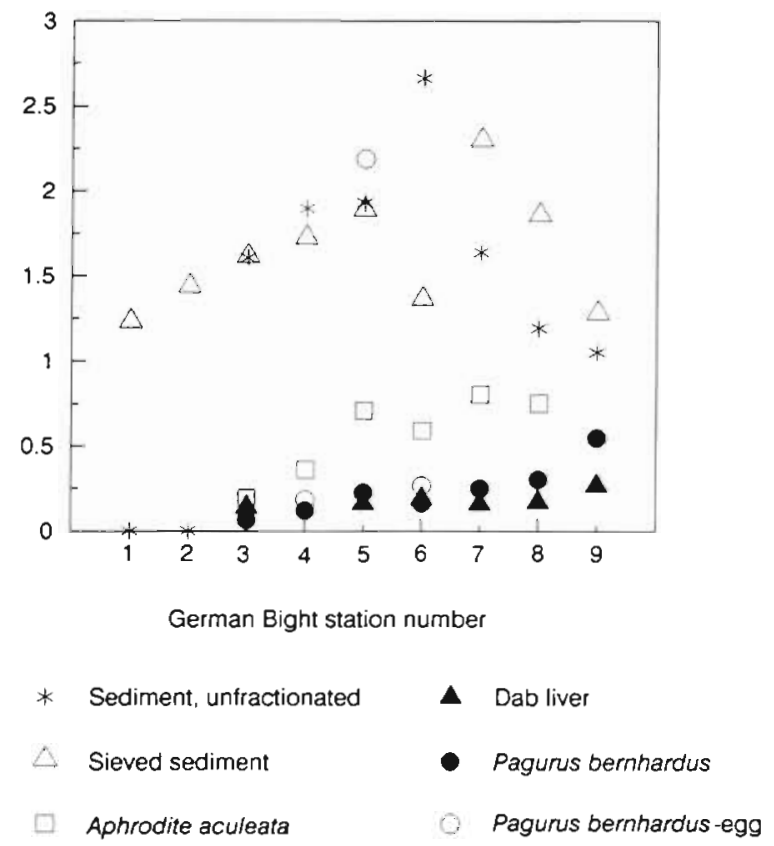

Fig. 3. Ratio of CB-28 to CB-180 along the German Bight transect, observed in unfractionated and sieved sediments, dab liver and benthic invertebrates equivalents from German Bight Stns 1 to 9, reflecting the increasing coarseness of the sediments. The THCGC concentrations were low and variable, with a maximum value of $44 \mathrm{\mu g} \mathrm{g} \mathrm{g}^{-1}$ dry weight seen at Stn 2 . In the $<63 \mu \mathrm{m}$ fraction the THC-UV concentrations were of the order of $100 \mathrm{~s}$ of $\mu \mathrm{g} \mathrm{g}^{-1}$ dry weight, with the highest values occurring at Stns $2 \& 9$, the latter station having a higher TOC than other stations along the transect. THC-GC concentrations were variable and showed no systematic spatial gradients.

Along the drilling site transect, the THC-UV revealed almost no gradient in either the total or the $<63 \mu \mathrm{m}$ sediment fractions. This is not surprising for 2 reasons: (1) at the site a single exploration well was drilled using a low aromatic oil-based drill-mud; (2) as previously mentioned, a cover of sand had recently been deposited by storms over the original sediment surface.

THC-GC concentrations were again variabie, although chromatograms typical of those seen in areas contaminated by weathered base-oils (cuttings) were seen in total sediment samples from Stns A to E inclusive, absolute concentrations often being low. No sign of such contamination was observed in the $<63 \mu \mathrm{m}$ samples. Two possible reasons suggest themselves: (1) the cuttings discharged from this well site were coarse (predominantly $>63 \mu \mathrm{m}$ ), but this seems unlikely as normally they are finer; (2) the wet sieving procedure used in sediment fractionation allowed the low aliphatics to be washed from the sediment. Neither reason can be proven at present.

\section{Polycyclic aromatic hydrocarbons}

Unfractionated sediments. A gradient in concentrations up to about 100 times could be seen in the German Bight reflecting the increasing coarseness of the sediments. This was much steeper than the gradient observed at the drilling site, which was in most cases less than 5 times. The range of concentrations observed was similar to that found previously in the northeastern Irish Sea prior to the development of the Morecambe Bay gas field (Law et al. 1989), where the concentrations and the gradient were of a similar order to those observed in the German Bight.

Sieved sediments. Concentrations of specific PAH showed much less variability and no clear gradient in the $<63 \mu \mathrm{m}$ fraction. This suggests that the bulk of the PAH are carried with the fine sediment particulates and dispersed widely into the coarser offshore sand.

Benthic invertebrates. The lipid-normalized concentrations of PAHs in Aphrodite aculeata were all consistently higher than in Pagurus bernhardus. The $A$. aculeata sample collected at $\operatorname{Stn} 3$, which was quite 
silty, exhibited relatively high concentrations for all PAHs studied. PAHs in A. aculeata and P. bernhardus samples collected at the German Bight Stns 4 to 8 and 9 respectively did not show a spatial trend.

The drilling site transect differed in this respect. For all PAHs, lipid normalized concentrations in Aphrodite aculeata decreased from Stn A to G. This trend was not observed in Pagurus bernhardus. REMOTS pictures obtained during the workshop indicate that a fresh layer of sediment had been deposited on the (probably) old contaminated layer (Rumohr \& Schomann 1992). P. bernhardus is an epibenthic species, whereas A. aculeata belongs to the endofauna. A possible explanation might be that $P$. bernhardus was more or less isolated from the contaminated sediment, so that all drilling site stations rendered more or less the same PAH concentrations. A. aculeata may have been more in contact with the contaminated material and therefore reflected the PAH gradient. The sediment data do not provide guidance in this respect as they correspond with freshly deposited material. The differences may also arise, however, from differences in biotransformation. In addition, the gales may have resulted in a redistribution of $P$. bernhardus in the area. With the present dataset, no scientifically justified explanation can be given for the observations.

\section{CONCLUDING REMARKS}

The conclusions from the chemistry programme would have been more secure if the sampling programme had been carried out as planned. A future workshop would benefit from active participation by more chemists, taking care of sampling and contributing to the research projects.

Trends in contaminant concentrations are most conveniently assessed in sieved sediments and biota. Along the German Bight transect, contamination declined with respect to nearly all constituents studied. $\mathrm{Cd}$ may form an exception, but the spatial trends are different between the environmental compartments studied. The station on the eastern side of the Dogger Bank (Stn 9) has particular characteristics. The organic carbon and total nitrogen content and the concentrations of $\mathrm{Cd}, \mathrm{Hg}$ and $\mathrm{Pb}$ in sieved sediments were significantly higher than the concentrations found at other locations. These observations are in line with the findings of other studies conducted in this area.

The ratio of relative volatile chlorobiphenyls (e.g. CB-28) to CB-180 is found to increase in sediments along the German Bight transect. This finding may point to the effects of atmospheric deposition becoming more important in offshore areas.

The lipid normalized concentrations of PCBs appear to be quite similar for different species. This result underlines the importance given to the role of partitioning in the distribution of PCBs as indicated by sev. eral authors.

The results for the drilling site transect were probably affected by the deposition of fresh sediment by gales prior to the workshop. The spatial trends in PAH concentrations differed for Aphrodite aculeata and Pagurus bernhardus. This difference may be related to differences in exposure. A detailed investigation would be required, however, to elucidate this finding.

Acknowledgements. The analyses of hydrocarbons in sediments and of trace metals in sediments and dab liver were funded under contract to the UK Department of the Environment as part of its coordinated programme of research on the North Sea. This is publication no. 42 of the project Applied Scientific Research (BeWON), Netherlands Institute for Sea Research.

\section{LITERATURE CITED}

Boon, J. P., Duinker, J. C. (1985). Kinetics of polychlorinated biphenyl (PCB) components in Juvenile Sole (Solea solea) in relation to concentrations in water and to lipid metabolism under conditions of starvation. Aquat. Toxicol. 7: $119-134$

Boon, J. P., van Zantvoort, M. B., Govaert, M. J. M. A., Duinker, J. C. (1985). Organochlorines in benthic polychaetes (Nephtys spp.) and sediments from the Southern North Sea. Identification of individual PCB compounds. Neth. J. Sea Res. 19: 93-109

Delbeke, K., Joiris, C. (1988). In: Newman, P. J., Agg, A. R. (eds.) Environmental protection of the North Sea. Heinemann Professional Publishing Ltd, Oxford, p. 771-779

Duinker, J. C., Hillebrand, M. T. J (1978). Minimizing blank values in chlorinated hydrocarbon analysis. $J$. Chromatogr. 150: 195-199

Freimann, P., Schmidt, D. (1989). Application of total reflection X-ray fluorescence analysis for the determination of trace metals in the North Sea. Spectrochim. Acta 44B: 505-510

Freimann, P., Schmidt, D., Schomaker, K. (1983). MERCOS, a simple teflon sampler for ultratrace metal analysis in sea water. Mar. Chem. 14: 43-48

Hendrix, C. (1979). What every technologist should know about experimental design. Chemtech., March 1979: $167-174$

ISEPNS (International Symposium on the Pollution of the North Sea) (1988). Discussion about the Dogger Bank. In: Newman, P. J., Agg, A. R. (eds.) Environmental protection of the North Sea. Heinemann Professional Publishing Ltd, Oxford, p. 857-859

ICES (1989). Working Group on Biological Effects of Contaminants. Report on meeting in Aberdeen May 1989. ICES C.M./E: 29 pp.

Jensen, S., Renberg, L., Reutergårdh, L. (1977). Residue analysis of sediment and sewage sludge for organochlorines in the presence of elemental sulfur. Anal. Chem. 49: 316-318

Klamer, J. C., Hegeman, W. H., Smedes, F. (1990). Comparison of grain size correction procedures for organic micropollutants and heavy metals in marine sediments. Hydrobiologica 208: 213-220 
Knickmeyer, R., Steinhart, H. (1988). Seasonal differences of cyclic organochlorines in eggs of the hermit crab Pagurus bernhardus L. from the North Sea. Sarsia 73: $291-298$

Law, R. J., Fileman, T W., Portmann, J. E. (1988). Methods of analysis of hydrocarbons in marine and other samples. Aquat. Environ. prot.: Analyt. Meth., MAFF Direct. Fish. Res., Lowestoft, (2), 25 pp.

Law, R. J., Fileman, T. W., Fileman, C. F., Limpenny, D. (1989). The distribution of hydrocarbons and metals in the northeastern Irish Sea prior to development of the Morecambe Bay gas field. Oil. Chem. Pollut. 5: 285-320

Pagee, J. A van (1988). Contribution to discussion about the Dogger Bank. In: Newman, P. J., Agg, A. R. (eds.) Environmental protection of the North Sea. Heinemann Professional Publishing Ltd, Oxford, p. 857-859
Rumohr, H., Schomann, H. (1992). REMOTS sediment profiles around an exploratory drilling rig in the southern North Sea. Mar. Ecol. Prog. Ser. 91: 303-311

Schmidt, D., Freimann, P., Zehle, H. (1986). Changes in trace metal levels in the coastal zone of the German Bight. Rapp. P.-v. Réun. Cons. int. Explor. Mer 186: 321-328

Schmidt, D., Wendlandt, U. (1987). Spurenbestimmung von Quecksilber im Meerwasser der Nordsee. In: Welz, B. (ed.) 4. Colloquium Atomspektrometrische Spurenanalytik, Konstanz, April 1987 Bodenseewerk Perkin-Elmer \& Co., Überlingen, p. 617-628

Sokal, R. R., Rohlf, F. J. (1981). Biometry. W. H. Freeman and Co., New York

Stebbing, A. R. D., Dethlefsen, V. (1992). Introduction to the Bremerhaven Workshop on Biological Effects of Contaminants. Mar. Ecol. Prog. Ser. 91: 1-8 